\begin{tabular}{l} 
RCCS \\
\hline Annual Review
\end{tabular}

\section{RCCS Annual Review}

A selection from the Portuguese journal Revista Crítica de Ciências Sociais

6 | 2014

Issue no. 6

\title{
Beyond Binarism? Intersex as an Epistemological and Political Challenge
}

\section{Ana Lúcia Santos}

Translator. Karen Bennett

\section{OpenEdition}

\section{Journals}

Electronic version

URL: http://journals.openedition.org/rccsar/558

DOI: $10.4000 /$ rccsar.558

ISSN: $1647-3175$

\section{Publisher}

Centro de Estudos Sociais da Universidade de Coimbra

\section{Electronic reference}

Ana Lúcia Santos, « Beyond Binarism? Intersex as an Epistemological and Political Challenge », RCCS Annual Review [Online], 6 | 2014, Online since 01 October 2014, connection on 30 April 2019. URL http://journals.openedition.org/rccsar/558; DOI : 10.4000/rccsar.558 


\section{Ana Lúcia Santos}

Centre for Social Studies, University of Coimbra, Portugal

\section{Beyond Binarism? Intersex as an Epistemological and Political Challenge*}

Sexual difference combines various aspects, ranging from the biological to the social, which, once delimited, reduce people to two political categories: woman and man. Although these categories are not naturally watertight, most societies reject diversity (understood as deformity) in favour of a binary sexual system. This article aims to deconstruct this binarism, suggesting that it is not coherent to speak of two sexes, but rather of a multiplicity. Based on feminist theory, queer theory and philosophy, the text develops a reflection on intersex, showing how it has been considered at different times. It also addresses the history of sexual regulation and discusses its causes and effects. Reflection on the concept of human being, which till now excluded intersex - by and large placed beyond the limits of the possible - leads to the interconnection of Butler's definition of the livable life with Derrida's notion of unconditional hospitality, which may be the key to the recognition of intersex as a human category.

Keywords: hospitality; intersexuality; human being; sexual system.

\section{Introduction: Defining the field}

In an interview to La Vanguardia (Amela, 2008), the philosopher Beatriz Preciado, asked about her identity as man or woman, replied: "That question reflects an anxious Western obsession [...] with wanting to reduce the truth of sex to a binomial." The Western sexual system, like most systems in the rest of the world, only allows for two sexes, something that is accepted as dogmatic truth and reproduced by most people. But to what extent is that binarism valid? And what are its consequences?

Human beings are meticulously measured and regulated inside and out, so that no one remains outside the recognised categories of "man" and "woman." However, there are people whose primary or secondary sexual characteristics do not fulfill medical and/or social requirements for inclusion in one or the other group. Sometimes there may be doubt about the genital sex at birth: the erectile organ may be too big for a "normal" clitoris or two small for a "normal" penis; the genitalia may be anatomically female but the vaginal labia include testicles; or they may include both penis and vagina. But it is not just at birth that ambiguities are found. What at the outset might seem "normal" may later reveal discrepancies in the genital organs and/or secondary sexual characteristics.

\footnotetext{
* Article published in RCCS 102 (December 2013).
} 
For intersex people, who physically defy sexual binarism, hormonal and/or surgical treatment $^{1}$ is imposed as a necessity, without alternatives (Fausto-Sterling, 2000a; Dreger, 2003). This basically involves a violation of the body ${ }^{2}$ using technologies to "normalize" it aesthetically so that it can be included in a category that is recognisably human, in Butler's sense (2004). ${ }^{3}$ Ideally undertaken at an early age, these "violations" do not just leave scars; they are physically imprinted upon a sex that transports with it an identity which, on its own, dictates part of the destiny of someone that never had any power of choice, something that can result in serious psychological consequences (Dreger, 1998).

The "treatment" for intersexuality (i.e. a medical solution designed to "correct"/ "normalize" and transform the intersex into one of the two recognised sexual categories) rests on ideologically consolidated grounds: machismo and sexism allied to heterosexuality (Santos, 2012). Contemporary medical models of sexual differentiation reflect the traditional connotations of masculine with activity and feminine with passivity (Preves, 2005: 26). Heterosexism is reflected in the main criterion used to assess the success of a treatment: sexual relations with the opposite sex (Fausto-Sterling, 2000b). A treatment is considered successful when the new sex coincides with the sexual identity to which that sex is associated and to the corresponding heteronormative orientation - for example, when a person who has been reassigned to the female sex duly complies with the stereotypes associated with that sex, assuming herself to be a heterosexual "feminine" woman (which brings aesthetic and behavioural implications). Thus, the success of treatment depends upon the congruence, from a heterosexual point of view, of sexual identity and the sex of creation (the sex to which the person has been reassigned). ${ }^{4}$ Cases in which there is a congenital absence of a vagina in a woman also bear witness to this triple ideology. This condition, known as Mayer-Rokitansky Syndrome or Müllerian agenesis is characterized by the

\footnotetext{
${ }^{1}$ Body modification techniques include sex reassignment surgery (SRS), hormone replacement therapy (HRT), mastectomy, vaginoplasty or phalloplasty.

${ }^{2}$ Intersex bodies are violated with the most sophisticated techniques. But, recalling Butler, all bodies are in fact violated. This philosopher claims that sexual categories operate as violations as they are not chosen but imposed, penalizing anyone who dares to refuse the norms established for each category (consequences may involve loss of employment, loss of parental rights, and even loss of life, among others) (Butler, 2004: 213-214).

${ }^{3}$ The question of human categories is explored in Section 2 of this article, "Recognition and humanity", based on Judith Butler, who theorizes on the categories that qualify as recognisably human.

${ }^{4}$ The way intersex is conceived is dominated by a series of engendered powers (medical, social, family, etc.). These powers are grounded in what Judith Butler first called the 'heterosexual matrix', in Gender Trouble, and later 'heterosexual hegemony'. The sexual matrix involves the norms that regulate subjects so that biological sex, sexual identity and desire work harmoniously together from the point of view of heterosexual logic.
} 
incomplete formation of the vagina, cervix, urethra and/or Fallopian tubes in individuals with $46, \mathrm{XX}$ genetic karyotype. ${ }^{5}$ Women born without a vagina undergo one or more surgical procedures accompanied by a painful process of dilation. This is done so that the women are able to have (hetero)sexual relations with vaginal penetration by a penis of "normal" size, even though this does not bring any physical pleasure to the women. ${ }^{6}$

In observing the genitalia of the newborn child, obstetricians stipulate the sex in accordance with the average dimensions and visual schema that they have in their minds. Thus, the sex does not depend upon its nature or on the way it appears, but the way in which it is perceived. Let us consider, as an example, the size of the erectile organ at birth: a penis that is less than $2.5 \mathrm{~cm}$ will be perceived as unable to penetrate a vagina in the future, and may therefore be amputated and a neovagina created. The sexes are thus cultural interpretations, and may be "repaired" if the size or shape is not considered acceptable (i.e. does not fall within "normal" parameters, in the medical and common understanding). Sexual variations are not limited to two, much less sexual or gender identity. If there were a consequential relationship between anatomical sex and gender, there would have to be space for a series of correspondences between other genital variations and genders.

Intersex, and the inability to deal with it, shows that the sexual system that dominates in the West is inadequate to express the highly varied spectrum of sexuality. As Anne FaustoSterling suggests in her famous article "The Five Sexes", published in 1993 in the journal The Sciences, "there are many gradations running from female to male" (21). The existence of intersex destabilizes the binary models of woman/man, female/male, homosexual/ heterosexual. Intersexuality is usually divided broadly into true hermaphroditism and pseudohermaphroditism, but there are other "normative ambiguities," which are mentioned less because they are less common. There may also be unusual features in the genitals that

\footnotetext{
${ }^{5} \mathrm{XX}$ and $\mathrm{XY}$ are pairs of sexual chromosomes, with the $\mathrm{XX}$ pair connoting the female seX and $\mathrm{XY}$ the male. There are 46 chromosomes in a somatic cell. However, the number of sexual chromosomes per cell may be greater or smaller than two. If a person has only one $X$ chromosome in each cell, then $\mathrm{s} /$ he will have a $45, \mathrm{XO}$ karyotype; if s/he has three chromosomes in each cell, s/he will have a $47, X X Y$ or $47, X Y Y$ karyotype. There are several chromosomal possibilities that may be considered to be of the intersex type.

6 Esther Morris, author of "The Missing Vagina Monologue", was born without a vagina and when this was discovered, when she was 13 , she underwent four operations to create a neovagina. When she began (hetero)sexual activity, she felt revolted, as everything she had gone through had not brought anything positive for her body. "After all that trouble, I discovered that a penis would respond to anything. I felt abused in the most intangible way, victim of arrogance and assumption" (Morris, 2001: 4).
} 
are not classified as belonging to the intersex type, such as macroclitoris and hypospadias. ${ }^{7}$ For this reason, it is difficult to obtain a reliable percentage of intersex births. Quoting Alice Dreger (2003: 40-42), "it is not possible to provide with any great certainty a statistic of the frequency of births in which the child's sex falls into question [...]. Such a statistic is always necessarily culture specific."

Dreger (ibidem) explores this impossibility of obtaining a universal statistic for the number of cases of intersexuality. For example, there is the so-called deficiency in the enzyme 5-alpha-reductase (5-AR) - responsible for one of two possible causes of male pseudohermaphroditism and which is genetic in cause: in isolated places where intermarriage occurs, the lack of genetic variety contributes to a preponderance of that enzyme variation in the genes, if it has previously been present in some lineage. In isolated regions of the Dominican Republic, there is a population that manifests much greater frequency of this deficiency due to lack of genetic variety (Dreger, 2003: 40; Preves, 2005: 40), so that the tendency for this kind of male pseudohermaphroditism is probably greater there than anywhere else. The cultural factor is also relevant to this question of statistical data: there are, for example, cultures in which the sex is rarely examined, which makes it impossible to know and record the incidence rate. Cultures that consider large clitorises or small penises to be unacceptable will tend to present statistically more cases of intersexuality than those that consider them to be of "normal" size (Dreger, 2003: 42). The generational factor is also relevant: we might recall the hormonal treatment given to many women in the United States in 1960 to prevent miscarriage, which led to a surge in births of children with congenital adrenal hyperplasia (ibidem: 41). Nevertheless, Dreger suggests an incidence rate of one to three cases of intersex for every two hundred births in the United States (ibidem: 42), while Sharon Preves (2005: 2), based on an exhaustive survey of the medical literature, indicates one to four cases of intersex for every hundred births.

Thus, the notion and naming of intersex differs from culture to culture and from generation to generation. For Aristotle, hermaphroditism involved the existence of an extra, non-functional, sex, which was added onto the true functional sex like a tumour. The cause

\footnotetext{
${ }^{7}$ Hypospadias is a condition in which the urethra does not open onto the gland of the penis but somewhere along it, which makes it difficult to urinate standing up. This is of course highly symbolic for masculinity, which is why it is considered important to operate early.
} 
of such "deformities" lay in the quantity of matter supplied by the mother (Long, 2006: 14). ${ }^{8}$ Until the 19th century, the male genitalia were seen as superior to the female, and the female genitalia were considered to be an underdeveloped version of the male, an unfinished organ (Dreger, 2003: 34). Thus, if a woman had "overdeveloped" genital organs, she would be similar to a hermaphrodite or to a man, while a man with "underdeveloped" genital organs would be similar to a woman or to a hermaphrodite (ibidem: 35 ). In the Medical Encyclopedia (Watson, 1900: 491), hermaphroditism is presented as a camouflaging of the true sex by means of malformations, and the term is still applied to cases where individuals present gonads from both sexes.

In the sphere of biology, the term "intersexuality" was first used by the geneticist Richard Goldschmidt in his article "Intersexuality and the Endocrine Aspect of Sex," published in the journal Endocrinology in 1917, in which he refers to a series of sexual ambiguities, including hermaphroditism (Dreger, 2003: 31). However, the term had already been used by other authors to refer to homo- and bisexuality, and even Goldschmidt considered homosexuality to be a form of intersexuality. The word "Intersexuality" gained popularity following his article as a replacement for the term hermaphroditism, and has prevailed in medical literature since the middle of the $20^{\text {th }}$ century. Today, it is used in biomedicine to refer to sexual variations in relation to the external genitalia or other features. In short, we might say that intersex is the circumstance in which the harmony between the sexual chromosomes, sexual hormones, genitalia, gonads (testicles and ovaries) and secondary sexual characteristics evades the criteria stipulated for the categorization of a person as male or female, which makes it impossible to determine their "overall sex."

This article begins by describing the processes of sexual regulation in the West, paying special attention to the way intersex is subjected to those processes while challenging them at the same time. Foucault's History of Sexuality will serve to demonstrate the parallelism that has run through intersex bodies since the Middle Ages, with a focus on their power of transgressing laws. His notion of biopower also helps us understand the processes of control of human life, specifically the sexual control of the population that began in modern Western societies in the $18^{\text {th }}$ century and continues to this day. Judith Butler's notion of

\footnotetext{
${ }^{8}$ According to Aristotle, the mother provides the "substance" (or matter) and the father the "form" (specific characteristics). This belief is grounded in his hylomorphic theory, which holds that everything is composed of matter and form.
} 
recognition (from Undoing Gender, 2004) is useful for discussing sexual regulation, since only people who have been subjected to processes of regulation are recognised as human beings and can have a livable life. Finally, Derrida's notion of hospitality is used to suggest a possible solution for achieving a livable life for that category that has not yet achieved recognition the category of intersex.

\section{Sexual regulation and normativities}

Transsexuals, homosexuals and intersex people have always existed. ${ }^{9}$ However, they have tended throughout history to be classified as anomalous or sick. Let us examine some of the factors underlying this tendency.

Sexual difference and apparent anatomic fact serve only to legitimize political organization (Preciado, 2008: 61-62) and perpetuate power relations. ${ }^{10}$ When a body has an ambiguous appearance, everything will be done, technologically and otherwise, to fit it into the normal pattern of sexual difference, thereby preventing that body from destabilizing the organization of society. Sexually ambiguous bodies are controlled by medicine and subjected to "normalization" procedures so that sex, body, behaviour, sexuality and secondary characteristics will function in harmony with each other and conform to the ideology of a heterosexist society. Like Foucault's "docile bodies" (2001), they are expected to be productive and submissive. For this reason, the study of intersexuality stopped being the exclusive province of medicine and biology, and became the purview of other areas, such as sociology, anthropology, feminism and queer studies.

Foucault (2003: 68-71) considered that the "hermaphrodite monsters" of the $18^{\text {th }}$ century were lucky compared to those that lived between the Middle Ages and the beginning of the

\footnotetext{
${ }^{9}$ To begin with Greek mythology: the hermaphrodite figure par excellence is of course Hermaphroditus, son of the god Hermes and the goddess Aphrodite, who was transformed into an androgynous being after union with the nymph Salmacis. Tiresias is the epitome of the transsexual being, having lived both as a man and as a woman at different times in his life. Sardanapalus, king of Assyria in the 7th century BC, wore women's clothing, as did the Roman emperor Elagabalus in the $3^{\text {rd }}$ century. In the 17th century, Kristina Augusta, Queen of Sweden, was considered bisexual; she had mannerisms considered to be masculine and a deep voice, wore male clothing and even renamed herself Count Dohna. Geneviève d'Eon, a spy for King Louis XV of France (18th century), lived half her life as a man and the other half as a woman. Herculine Barbin (Barbin and Foucault, 1980), a famous hermaphrodite who was registered and raised as a girl, was coerced into changing her identity in adulthood after being considered a man by the doctors, who attested to the existence of a penis (though she also had a vagina); shortly after assuming her new identity, Herculine committed suicide.

${ }^{10}$ According to Preciado (2008: 86-87), the production of sexual difference owed much to techniques of representing the body through anatomical and pornographic drawings, developed from the 17th century onwards, and particularly the invention of photography in the early $19^{\text {th }}$ century, which gave visual realism and the quality of truth to difference.
} 
17th century, who were burned alive for having two sexes (one of which had allegedly been attributed by Satan after coitus with him). After the 17th century, people were no longer convicted for hermaphroditism, but rather for having sexual relations with people of the same sex (it was now obligatory to choose one of the sexes - as still happens today in many countries). That is to say, conviction was caused by behaviour rather than the nature of the body, reflecting the $19^{\text {th }}$ century shift in the way monstrosity was perceived: it lost legalnatural status and acquired legal-moral status instead. The choice of one of the sexes only served to determine what clothes to wear, whether one was obliged to marry and with whom (someone of the opposite sex) (Foucault, 2003: 71-74). This type of monstrosity upset legal regularities, not only in the sphere of marriage but also as regarded baptism and rules of succession. Today, as in the Middle Ages, intersex people still destabilize the so-called "natural" principle, the moral principle and the laws. They cast doubt on the medical system, the legal system and the organization of institutions. In athletics, for example, new regulations were drawn regarding "the eligibility of athletes who have undergone male to female sex reassignment to compete in International Competitions [...] in the female category" (IAAF, 2011: 1). The International Olympic Committee and the International Association of Athletics Federations also established a policy regarding female athletes who have what they consider to be an unusual hormonal development for a woman. According to Article 1.3 of the IAAF Regulations Governing Eligibility of Females with Hyperandrogenism to Compete in Women's Competition, "No female with hyperandrogenism shall be permitted to compete in the female category of an International Competition until her case has been evaluated by the IAAF in accordance with these Regulations." Then there is the case of Alterina Hofan, an intersex person who was arrested in Indonesia in 2010 accused of falsifying documents, and who spent a distressing spell in prison, transferred from a male gaol to a female one and finally ending up in solitary cell, due to the uncertainty on the part of the police as to whether this was a man or a woman (Yessir, 2010).

According to Foucault (1978), it was in the $18^{\text {th }}$ century that the process of rationalizing, classifying and regulating sex got under way. It was also in that period that interest burgeoned in the sexuality of children, "mad" people, criminals and homosexuals (i.e. "deviant" sexualities). Discourses on this issue multiplied during the $19^{\text {th }}$ and $20^{\text {th }}$ centuries, 
and with them the "perversions." ${ }^{11}$ Norms of sexual development were stipulated in accordance with age, and perversions were condemned in court; anyone that practised sexual irregularities was considered mentally ill, and controlled pedagogically or through medical treatment (ibidem: 36). Behaviour became the object of analysis and interpretation on the part of institutions such as medicine, psychiatry, and criminal justice, and sexual behaviours in particular were examined with the aim of constituting a "sexuality that is economically useful and politically conservative" (ibidem: 37). Sexuality was controlled by institutions of knowledge and power, and discourses on sex became sites of power which could be unsettled by ambiguous sexes. For example, hermaphrodites were considered to be criminals or "crime's offspring" due to their anatomy, which "confounded the law that distinguished the sexes and prescribed their union" (ibidem: 38).

With the rationalization of the discourses around sex, and subsequently the increase in access to medical care (including gynaecological care), there was a multiplication of discourses and narratives, particularly medical publications, which produced a sudden apparent increase in cases of atypical sex in the $19^{\text {th }}$ century. The proliferation of assumed homosexuals and feminists also contributed to this, as they were considered "behavioral hermaphrodites" who defied the limits of sexuality (Dreger, 2003: 26). The consequences of this diversity were reflected in an overly rigorous delimitation of masculinity and femininity on the part of the medical and scientific communities, which categorized as unusual, unnatural and immoral anything that did not fit into the pattern. It became inconceivable not to try to normalize the situation of a hermaphrodite after birth. Thus, from the middle of the $20^{\text {th }}$ century, the first sex reassignment operations took place, procedures that were insecure and risky (Dreger, 2003; Fausto-Sterling, 2000a).

The need to control the life of the population dates back to the $18^{\text {th }}$ century, when the efforts that had till then been made to protect the sovereign's life began to be applied to the population. The defence which, till then, had been located on the level of legal (sovereign) existence shifted to biological existence, to be positively exercised over the population: "the ancient right to take life or let live was replaced by a power to foster life or disallow it to the point of death" (Foucault, 1978: 138). Power devoted itself to the maintenance and management of life, and a set of theories was generated to subject bodies and control the

\footnotetext{
${ }^{11}$ These "perversions" were not newly discovered forms of sexuality. They had always existed, but were now catalogued and pathologized.
} 
population, thereby instituting the era of biopower. Adapting this theory to today: when an intersex person is born, political power is inscribed in the bios and alters that body. This alteration is no more than the defence of the interests of the population in general disguised as the "defence" of the wellbeing of the intersex person, as the organization of most societies is not prepared to include intersex bodies or genderqueer identities. Something that appears to be a positive power for the wellbeing of the intersex person is, in the end, the only solution that the medical authorities have found to compensate for their own inability and that of most institutions to deal with a different sex, as they do not know how to position it in society. ${ }^{12}$ Sex reassignment surgery is performed in the name of the wellbeing of the population, so as to preserve its organizational system. The power that began to be deployed in the $18^{\text {th }}$ century to sustain the life of the population still persists. However, this protection of life continues to "cause death," or in Butler's terms, continues to undo (Butler, 2004) other possibilities for existence, other forms of being.

\section{Recognition and humanity}

According to Judith Butler (1999: 178-79), the subject (as gender) is defined through the acts s/he carries out in successive performances, and therefore is an effect, rather than the cause, of those acts. This means that sexual identity (or gender) is an effect of repeated acts on the body. In other words, it is the repetition of acts that endows the subject with sexual identity, and this identity is a category that results from the effect of institutions, practices and discourses. That repetition will lead to the recognition of the subject as woman or man (because gender as practice occurs amidst constraints), and in the last analysis as human, because only these two categories are recognised as being endowed with humanity. Influenced by the importance attributed by Hegel to the question of desire for recognition, Butler (2004: 2) considers that sexual identity is driven by desire in the search for recognition, making it into a site of power. She wonders: "If I desire in certain ways, will I be able to live?" This question lies at the heart of her argument, as Butler calls attention to the mutability of the terms by which each individual is recognised as a human being: if in some cases those terms confer humanity on certain people, in other cases the very same terms

\footnotetext{
${ }^{12}$ Nowadays, the destiny of the intersex child is decided by endocrinology, paediatrics, urology, psychology, surgery and genetics. Where there is genital atypicality, the sex is reassigned based on potential female reproductive capabilities, or on the size of the penis or clitoris (Fausto-Sterling, 2000a; Dreger, 1998).
} 
may deprive others of the same status, throwing them into anonymity, and, in the last analysis, into non-existence. "I may feel that without some recognizability I cannot live. But I may also feel that the terms by which I am recognized make life unlivable" (ibidem: 4). While, on the one hand, there are people that demand recognition as men or women, on the other, there are those that demand a kind of recognition that evades those constraining categories, aiming for recognition as human beings with autonomy over their bodies, free from medical manipulations and discursive constraints. Until the norms that regulate the world are reconsidered and the world reorganized, the sites of power will always be codified by binarism, and all bodies, not only intersex ones, are its victims.

In Undoing Gender (2004: 1), Judith Butler reflects on the consequences of a life lived on the margin of the dualist gender patterns prevailing in society, which ultimately implies the non-recognition of the person as a human being, as the normative conceptions of sex may prevent someone from leading a livable life, ${ }^{13}$ which Butler calls becoming undone. It is vulnerability that defines the human, the human condition. Once inserted into society, human beings are determined by its norms and defined by what they dictate, otherwise they are excluded. Therefore, in accordance with one of two sexes that are assigned, or reassigned to us, there will be a pattern of social practices to follow which have little to do with those governing the "opposite sex." It is the norms that constitute sex and determine us, as our destiny will be defined through it. Though the norms permit the construction of the subject, which is an imposed condition, they also make it impossible for it to be constructed in any other way. In the case of intersex people, they have to undo themselves, rid themselves of what they are, in order to construct themselves in another way; they cease to be intersex in order to be of female sex (and gender) or male sex (and gender). In Butler's words, it is the norms that do us, constructing us in a particular way, while at the same time undoing us, preventing us from constituting ourselves in another way. "The thought of a possible life is only an indulgence for those who already know themselves to be possible. For those who are still looking to become possible, possibility is a necessity" (Butler, 2004: 219). Intersex people are those that are still waiting for it to become possible for them to exist, that is, to be recognised. Paraphrasing Beatriz Preciado (2008), political intervention is

\footnotetext{
${ }^{13}$ In Undoing Gender, Butler develops the notion of the "livable life." A person can only have a livable or bearable life if they live in accordance with the norms that enable them to be recognised as human beings. Butler suggests that we rethink the limits of humanity and question the terms that constrain the lives of certain people.
} 
necessary for a reprogramming of sex. That intervention is not utopian. The definition of what it means to be human varies from culture to culture; there are no immutable definitions in space or time; concepts are always open to resignification, and categories are always subject to change. The same occurs with people and the world.

\section{The recovery of difference through Derridean hospitality}

Recalling Rosi Braidotti (2011: 138), "difference" is a central concept in the European history of philosophy, which, based on binary oppositions, created categories of alterity that acquired connotations of inferiority. This notion of difference was adopted by hierarchical and exclusionary modes of thinking, particularly by totalitarian regimes, which viewed difference as biologically determined and used it as a pretext for the extermination of thousands of people. Today, rather than being exterminated, difference is primarily transformed into sameness. As happens in dictatorial regimes with respect to difference, intersex is taken as a pejorative difference and is censured in society, manipulated by medicine and by the discourses that sustain the social order. It has become the place of the other, till now occupied (in the European context) by Jews, homosexuals, gypsies, the female sex and the disabled, amongst other minorities. Intersex is the other sex and the other being, deprived of recognition as human. However, this 'other' may be recovered and exalted by hospitality, achieving the status of human condition as such.

From Sophocles to Derrida, the word "hospitality" underwent various shifts of meaning. While for Plato and Kant, it is the human being as citizen (i.e. the legal-political subject) that is deserving of hospitality, for Levinas and Derrida, hospitality is due to all subjects in the human condition, and the duty to receive and shelter is no longer legal but absolute. This question is directly connected to the question of recognition, discussed by Butler (2004), which makes possible a livable life. Butler argues for a broadening of the term 'human' so that the person who is recognised as such can have a livable life. This idea comes close to Derrida's ethics, according to which hospitality (comparable to a form of livability/ habitability) should be extended to all others. Hospitality, as explored by Derrida in of Hospitality (2000), allows us to place the intersex in the role of the foreigner receiving hospitality in the Greek context. Derrida develops the idea using the works of Plato and the 
notion of the other ${ }^{14}$ of hospitality in the Biblical context, particularly the scene of Genesis in which Sarah and Abraham receive three uninvited guests.

Hospitality in the regime of the absolute is unconditional hospitality, the law above laws that clamours incessantly for justice. While on the one hand we have the invited guest, whose arrival is anticipated from the outset, on the other we have the visitor who interrupts normativity without warning, causing a disturbance - this is an event. Unconditional hospitality is that which is extended to each and every other irrespective of sex, religion, nationality, name, etc., unlike conditional hospitality (that of Plato and Kant), which, governed by laws, is offered only to the invited individual - the foreigner (someone that comes from outside) or the citizen of the polis - not to an absolute, enigmatic other.

The word 'hospitality' has its roots in the Latin hospitalitas, which refers to the act of hosting. As Benveniste (1969) shows in his detailed analysis of the etymology of this word, it includes elements with opposite meanings, ${ }^{15}$ thus suggesting the threat that hospitality brings with it; that is to say, the hostility at the heart of hospitality alerts us to its own danger. "There is no pure hospitality, it is impossible; in its unconditionality, it is only possible when (already) contaminated by hostility" (Bernardo, 2002: 443). ${ }^{16}$ When we receive someone into our home, we are not free of the risk that that person could negatively affect our inner world. Nevertheless, as hosts, we are obliged to take care of the person received on an equal footing.

When an intersex child is born, the host (the medical establishment, the family, society or the world generally) exceeds the bounds of the power (potis) associated with its condition, dictating rules and establishing limits that the intersex, as guest, may not transgress. In this

\footnotetext{
${ }^{14}$ The world "other" will be used here in the sense that it acquired in Derridean ethics. Unlike the "other" of feminism, which is a secondary other, this other is absolutely other ("tout autre"), absolute alterity, irrespective of any identity subsequently attributed to it, which precedes the "I" and from which the "I" recognises its existence. "Before I am, I carry, before being me, I carry the other. I carry you and must do so." (Derrida, 2005: 162). The relationship between the I and the other is a relationship of asymmetrical heteronomy, dominated by the singular primacy of the other to whom I am obliged ("il faut") to respond. The other is situated on the level of the living being, so that the animal is also other, prior to me, before me, in me and outside me (cf. Derrida, L'animal que donc je suis).

${ }^{15}$ Hospitalitas derives from hospitalis (hospitable), which comes from hospes (host; guest, visitor; stranger, foreigner), a compound of hostis (enemy, stranger) and the root of potis (owner, master; able, capable).

${ }^{16}$ Derrida uses the word hos-ti-pitality to refer precisely to the ambiguity of hospitality, "to refer to unconditional hospitality interrupted and contaminated or perverted by hostility" (Bernardo, 2002: 422).
} 
dynamic, the host itself ends up being the hostile one, in anticipating the potential hostility of the intersex - or a revolution in the sexual order of society. ${ }^{17}$

Evoking Montandon (2004), everything begins at the threshold of the door. The threshold represents a line that separates the host from the guest, and leads the latter to commit the first violence: the act of transgression in crossing the line, though that act implies acceptance of the host's rules. According to Montandon (2004: 7), "for the guest, this crossing tacitly implies acceptance of the rules of the other." A biological woman gives birth to a child. While that child is still attached by the umbilical cord, it is maintained at the threshold of hospitality, but as soon as this is cut, the first violation occurs. The newborn is led to transgress the frontier between its home (the amniotic sac), and the house of the world. It becomes hostage ${ }^{18}$ to the curious gaze of the obstetricians who, considering the danger underlying the event that has come from outside, do not waste time in looking for the mark that they consider distinctive of humans (sex). How perturbed they feel when they discover that this bold creature has committed another transgression: it has brought with it ambiguity! Having arrived without warning, this unexpected being has broken the binary norm of the sexes, while at the same time presenting itself as submissive to it.

All sexes, and particularly intersex, come into the world weighed down by a subjection to rules so that they can achieve what Butler (2004) calls a livable life. I challenge this subjection and this false hospitality, since the reception given to the intersex should not be viewed as an act of power that establishes from the outset a relation of dissymmetry with the guest (intersex person) submissive to the sovereign host (each and every other that receives him/her); rather it should be perceived as a gift, ${ }^{19}$ responding unconditionally and responsibly to the urgent appeal for hospitality. ${ }^{20}$ The law of unconditional hospitality that Derrida discusses in Of Hospitality is legally and politically impossible as law: if the world is thought of as a home, then geographic space should be considered from the perspective of hospitality, an archi-originary, pre-political, pre-social and pre-legal unconditional

\footnotetext{
17 "This is the fearful question, the revolutionary hypothesis of the Foreigner," Derrida claimed (2000: 7). The foreigner is the other whose arrival upsets the established order, analogous to what happens with intersex, which reminds us of the false duality of the sexes.

18 "Le sujet est otage" (Levinas, 1978: 177).

${ }^{19}$ The gift is implicitly a donation without economy, without exchange. Unconditional hospitality is a gift as such, unlike conditional hospitality, which implies an exchange-based economy (see Derrida, 1991).

${ }^{20}$ Abraham responded unconditionally to his mysterious visitors. This is "the great founding scene of Abrahamesque hospitality" (Derrida, 2000: 153).
} 
hospitality. ${ }^{21}$ Conditional hospitality, for its part, is legal-political since it imposes a series of laws upon the foreigner, who is conceived from the perspective of the polis. As well as being received in the form of a questionnaire, the foreigner is also obliged to respond in the language of the other. ${ }^{22}$ Despite being in his own city, Socrates presented himself before the judges as a foreigner to the language of the courts. "The foreigner is first of all foreign to the legal language in which the duty of hospitality is formulated" (Derrida, 2000: 15), and this is the first violence. Just as foreigners are obliged to speak a language that is not their own, intersex people are obliged to assume a sex that is not theirs, and are never able to acknowledge their sex as such, for unconditional hospitality is in the realm of impossibility, and doing the impossible is a challenge for an ethics of unconditionality. ${ }^{23}$ But the intersex differs from the foreigner in that the foreigner has a social status as a legal subject endowed with a name, while the intersex is (until sexually reassigned) an absolute other, without name or law, like a barbarian.

Unconditional hospitality may be defined by biological femaleness as a gestating body, since it is within the biologically "female" body that a child is generated, where it receives its first hospitality in an unconditional form, where the other is received as absolutely other, before there is any knowledge of it. Unconditional hospitality in the context of a binary sociosexual organization is absolutely impossible, as such binarism only exists to the extent that it is moulded from the multiplicity that is never received as such. What is required is an absolute hospitality that challenges conditional hospitality, not opposing or condemning it, but making it understand that it is necessary to receive each and every other. According to Derrida,

absolute hospitality requires that I open up my home and that I give not only to the foreigner (provided with a family name, with the social status of being a foreigner, etc.), but to the absolute, unknown, anonymous other, and that I give place to them [...] without asking of them either reciprocity (entering into a pact) or even their names. (2000: 25)

\footnotetext{
${ }^{21}$ Archi-originarity means that before the subject enters into "being" (as a social subject, a subject in law), it is subjugated to the absolute duty of the guest.

${ }^{22}$ In The Sophist, the foreigner is "someone that doesn't speak like the rest, someone who speaks an odd sort of language" (Derrida, 2000: 5). In The Apology of Socrates, Socrates presents "himself as like a foreigner, [...] as though he were a foreigner" (ibidem: 17).

23 "I question the impossible as the possibility of ethics: unconditional hospitality is impossible, in the field of law or politics, even in ethics in the strict sense of the term. Yet it is what must be done, the im-possible" (Derrida apud Bernardo, 2004: 18).
} 
This "without asking their names" may already imply a lack of interest in the sex, as the name, despite being considered by Derrida as a mark of singularity, is also a mark of sameness, given that most names aim at sexual differentiation through grammatical gender.

Absolute hospitality is from the sphere of justice, a just hospitality that breaks with conditional hospitality, which is from the field of law. Between the two, there is no delimited opposition; instead, there is a relation of heterogeneity (difference without opposition) and indissociability. Just hospitality impels legal hospitality to progression, but "it is as strangely heterogeneous to it as justice is heterogeneous to the law" (ibidem: 27). Laws (norms, rights, duties) require the Law (of justice) in order to be more just; and the Law, in turn, needs laws in order to acquire the meaning of existence; it needs to be able to intersect them and tell them what is wrong. It is necessary to make the impossible a goal and remove the state from the sphere of the private whenever it aims to legislate the body of the other in order to put an end to this biopower. According to Derrida, if the state interferes in private life, hospitality will be shattered: "the intervention of the State becomes a violation of the inviolable, in the place where inviolable immunity remains the condition of hospitality" (Derrida, 2000: 51). Foucault also shared the same aversion to this type of organization of power over life: "methods of power and knowledge assumed responsibility for the life processes and undertook to control and modify them" (Foucault, 1978: 142). A normalizing society is what results from the processes of a technology of power centred on life (ibidem). Whenever biopolitics operates in the form of normalizing disciplines which tend to produce "normal" identities and bodies, those mechanisms have to be rejected as being mechanisms for the normalization of sexuality.

Thus, we have an unconditional duty to receive the other without excuses, conditions or prejudices. We have to do Derrida's impossible and be unconditionally hospitable, infringe laws if necessary, just as he himself did when he accepted undocumented foreigners, knowing that this was forbidden, a crime even. ${ }^{24}$ Ethics, politics and law have to be reinvented. We have to be able to accept not only the invited guest but also the unexpected visitor with the human dignity that is due to both.

\footnotetext{
${ }^{24}$ The crime was called "offense of hospitality" [délit d'hospitalité] (vide Bernardo, 2002: 439).
} 


\section{Conclusion}

Having demystified intersex, we must conclude that sexuality cannot be reduced to a dichotomy. If the $19^{\text {th }}$ century was a golden age in terms of the known cases of intersex people, we are now heading towards the eradication of intersexuality through compulsory sexual reassignment surgery which channels a sexuality that is plural. Although ambiguous genitalia may imply metabolic disorders, as Alice Dreger (2000: 162) points out, the genitals are not sick in themselves. Treatments that aim at "aesthetic normalization" and inclusion into a sexual category will never lead to the emancipation of the intersex person. Rather than creating harmony between genitals and chromosomes, the body should be in harmony with the person that embodies it. Thus, it becomes imperative and urgent to de-pathologize intersexuality, and to stop performing, even criminalizing, surgery that is performed without the individual's consent.

Intersexuality urgently needs to be discussed as it is a controversial matter about which little is known. The question of intersex calls into question the other sexes, the frontier between them, ideals of beauty, sexual orientation, gender identity, legislation, medical services, ethics... Intersex is thus the key to a rupture with and resignification of sexual norms. We have to rethink sex, as Fausto-Sterling (1993) does, as a vast and malleable continuum. We have to rethink the norms and rethink the concept of human being.

Allied to Butler's question of recognition, Derridean hospitality may be the theoretical key for absolute inclusion, ${ }^{25}$ since without recognition people do not have dignity as humans, are not received by either the family, or by society in general. If unconditional hospitality is impossible, then we should do the impossible and make possible another mode of being.

Translated by Karen Bennett

Revised by Teresa Tavares

\section{References}

Amela, Victor (2008), "Entrevista con Beatriz Preciado, filósofa transgénero y pansexual," La Vanguardia, 1 April. Consulted on 05.02.2013, at http://www.sigla.org.ar/index.php?option=com content\&view=article\&catid=88: contenido\&id=3 02:preciado\&Itemid=136.

\footnotetext{
${ }^{25}$ This absolute inclusion aims to be a positive inclusion, which opens the way to all sexualities that do not imply asymmetrical relations - positive sexual anarchy (Santos, 2012) - excluding paedophilia, zoophilia and others based on relationships of power over others.
} 
Barbin, Herculine; Foucault, Michel (1980), Herculine Barbin - Being the Recently Discovered Memoirs of a Nineteenth Century Hermaphrodite. New York: Random House.

Benveniste, Émile (1969), "L'hospitalité," Le vocabulaire des institutions indo-européenes. 1. Économie, parenté et société. Paris: Les Editions de Minuit, 87-88.

Bernardo, Fernanda (2002), "A ética da hospitalidade, segundo J. Derrida, ou o porvir do cosmopolitismo por vir a propósito das cidades-refúgio, re-inventar a cidadania (II)," Revista Filosófica de Coimbra, 22: 421-446.

Bernardo, Fernanda (2004), "Como uma língua por inventar. A hospitalidade poética de Derrida," Phainomenon, 9 (Autumn): 9-67.

Braidotti, Rosi (2011), Nomadic Subjects: Embodiment and Sexual Difference in Contemporary Feminist Theory. New York: Columbia University Press [ $2^{\text {nd }}$ ed.].

Butler, Judith (1999), Gender Trouble. New York: Routledge.

Butler, Judith (2004), Undoing Gender. New York: Routledge.

Derrida, Jacques (1991), Donner les temps. Paris: Galilée.

Derrida, Jacques (2000), Of Hospitality. California: Stanford University Press.

Derrida, Jacques (2005), "Rams: Uninterrupted Dialogue - Between Two Infinities, The Poem," in Thomas Dutoit \& Outi Pasanen (eds.), Sovereignties in Question: The Poetics of Paul Celan. New York: Fordham University Press. 135-163.

Dreger, Alice (1998), “'Ambiguous Sex' or Ambivalent Medicine?" The Hastings Center Report, May/June, 28(3): 24-35. Electronic version consulted on 13.02.2013, at http://search.ebscohost.com/login.aspx?direct=true\&db=a9h\&AN=872328\&site=ehostlive\&scope=site.

Dreger, Alice (2000), "Jarring Bodies: Thoughts on the Display of Unusual Anatomies," Perspectives in Biology and Medicine, 43(2): 161-172.

Dreger, Alice (2003), Hermaphrodites and the Medical Invention of Sex. Cambridge: Harvard University Press.

Fausto-Sterling, Anne (1993), "The Five Sexes: Why Male and Female Are Not Enough," The Sciences, March/April, 20-24. Electronic version consulted on 13.02.2013, at http://capone.mtsu.edu/phollowa/5sexes.html.

Fausto-Sterling, Anne (2000a), Sexing the Body. New York: Basic Books.

Fausto-Sterling, Anne (2000b), "Five Sexes, Revisited," The Sciences, July/August, 17-23. Electronic version consulted on 13.02.2013, at http://www.aissg.org/PDFs/Five-Sexes-Revisited-2000.pdf.

Santos, Ana (2012), "Um sexo que são vários. A (im)possibilidade do intersexo enquanto categoria humana." Master's Thesis in Feminist Studies, Faculty of Arts and Humanities, University of Coimbra.

Foucault, Michel (1978), History of Sexuality: The Will to Know. Trans. by Robert Hurley. London \& New York: Penguin.

Foucault, Michel (2003), Abnormal. Lectures at the Collège de France (1974-1975). Trans. by Graham Burchell. London \& New York: Verso.

IAAF - International Association of Athletics Federations (2011), "Hyperandrogenism and Sex Reassignment." Consulted on 11.02.2013, at http://www.iaaf.org/aboutiaaf/documents/medical\#hyperandrogenism-and-sex-reassignment.

Levinas, Emmanuel (1978), Autrement qu'être ou au-delà de l'essence. La Haye: Nijhoff. 
Long, Kathleen (2006), Hermaphrodites in Renaissance Europe. Aldershot: Ashgate.

Montandon, Alain (2004), "Miroirs de l'hospitalité," in Alain Montandon (ed.), Le livre de l'hospitalité. Paris: Bayard, 6-13.

Morris, Esther (2001), "The Missing Vagina Monologue," Sojourner, Women's Health Edition, March. Electronic version consulted on 13.02.2012, at http://ebookbrowse.com/the-missing-vaginamonologue-and-beyond-pdf-d167409207.

Preciado, Beatriz (2008), Testo yonqui. Madrid: Ed. Espasa.

Preves, Sharon (2005), Intersex and Identity: The Contested Self. New Jersey: Rutgers University Press $\left[2^{\text {nd }}\right.$ ed. $]$.

Watson, Chalmers (ed.) (1900), Encyclopaedia Medica. Vol. 4. Edinburgh: William Green and Sons.

Yessir (2010), "Indonesian Court Says Alterina Hofan Is a Man," A BIG MESSAGE for an upside down world, $1^{\text {st }}$ December. Consulted on 13.02.2013, at http://www.abigmessage.com/indonesiancourt-says-alterina-hofan-is-a-man.html. 